\title{
Fuels, vegetation, and prescribed fire dynamics influence ash production and characteristics in a diverse landscape under active pine barrens restoration
}

\author{
K. M. Quigley ${ }^{1 *}$ (D, R. E. Wildt², B. R. Sturtevant ${ }^{3}$, R. K. Kolka ${ }^{4}$, M. B. Dickinson ${ }^{5}$, C. C. Kern ${ }^{3}$, D. M. Donner ${ }^{3}$ and
} J. R. Miesel ${ }^{1}$

\begin{abstract}
Background: An important consequence of wildland fire is the production of ash, defined as a continuum of mineral to charred organic residues formed by the burning of wildland fuels. Ash may impact soil health depending on its elemental composition and other factors, which are influenced by fuel quantity and quality, and by combustion completeness. To investigate how ash properties relate to variation in fuels and fire, we collected and analyzed ash samples following prescribed fires in a pine barrens landscape spanning grassland, shrubland, conifer woodland, and deciduous forest. At some plots, mechanical brush cutting was applied, and woody fuels were added or removed to experimentally manipulate fuel loads.

Results: Ash load averaged $2 \mathrm{Mg} \mathrm{ha}^{-1}$, or approximately $12.5 \%$ of fuel consumption, and was positively related to maximum temperatures estimated by temperature-sensitive paint tags. Ash load also increased in cut brush and fuel addition treatments. Fuel consumption in grasslands, estimated from maximum paint tag temperatures by calibration, was increased by woody fuel addition. Total nutrient stocks in ash was greatest at conifer sites (i.e., nitrogen, N; phosphorus, P; potassium, K; magnesium, Mg; and iron, Fe) and lowest at grassland sites (P; K; calcium, $\mathrm{Ca} ; \mathrm{Mg}$; and manganese, $\mathrm{Mn})$. Concentrations of leachable nutrients in ash were high for cations $\mathrm{Ca}\left(>20 \mathrm{~g} \mathrm{~kg}^{-1}\right)$, $\mathrm{K}\left(>4 \mathrm{~g} \mathrm{~kg}^{-1}\right)$, and $\mathrm{Mg}\left(>5 \mathrm{~g} \mathrm{~kg}^{-1}\right)$, which resulted in high ash $\mathrm{pH}$ (mean \pm standard error $\left.=8.4 \pm 0.1\right)$. Leachable cations were positively related to total ash cation concentrations, but leachable metal concentrations (Fe; Mn; copper, Cu) were low despite their high content in ash.

Conclusions: We observed differences in ash production and composition that corresponded to variation in vegetation cover, fuel loads, and paint tag temperatures. High concentrations of leachable cations in ash suggested that repeated prescribed fire may act to decrease cation availability in soils if cations are leached through sandy soils over time. In the case of pine barrens, prescribed fires, which decrease carbon (C) stocks while producing high concentrations of leachable nutrients in ash, may contribute to decreased soil nutrient stocks, and more limited tree growth, thus helping to maintain and restore critically endangered barrens ecosystems.
\end{abstract}

Keywords: brush cutting, disturbance, forest management, Moquah Barrens, pyrometer, restoration

\footnotetext{
* Correspondence: quigle44@msu.edu

'Department of Plant, Soil, and Microbial Sciences, Michigan State University,

1066 Bogue Street, East Lansing, Ml 48824-1222, USA

Full list of author information is available at the end of the article
} 


\section{Resumen}

Antecedentes: Una consecuencia importante de los incendios de vegetación es la producción de cenizas, definidas como un continuo que va desde sustancias minerales hasta residuos orgánicos carbonizados formados por el quemado de combustibles vegetales. Las cenizas pueden impactar en la salud del suelo dependiendo de composición elemental o de otros factores, los que están influenciados por la cantidad y calidad del combustible y por el grado como se completa la combustión. Para investigar cómo las propiedades de las cenizas se relacionan con variaciones en combustibles y fuegos, coleccionamos y analizamos muestras de cenizas luego de una quema prescripta en un paisaje de pinos en tierras yermas que abarcaban también pastizales, arbustales, bosques de coníferas y bosques caducifolios. En algunas parcelas fue aplicado el control mecánico de arbustos y algunos combustibles leñosos fueron agregados o sacados para manipular estas cargas.

Resultados: La carga de cenizas promediaron $2 \mathrm{Mg} \mathrm{ha}^{-1}$, o aproximadamente $12.5 \%$ del combustible consumido, y se relacionó positivamente con las temperaturas máximas estimadas mediante tarjetas pintadas con colores sensibles a cambios en la temperatura. La carga de cenizas también aumentó en las parcelas de arbustos que fueron mecánicamente tratados y en aquellas a las que se les adicionó combustible leñoso. El consumo de combustible en pastizales, estimado mediante calibración de las tarjetas sensibles a la temperatura, fue incrementado por la adición de material combustible leñoso. El stock total de nutrientes en las cenizas fue mayor en los sitios de bosques de coníferas (i.e., nitrógeno, N; fósforo, P; potasio, K; magnesio, Mg; y hierro, Fe) y menor en los sitos de pastizal ( $\mathrm{P} ; \mathrm{K}$; calcio, Ca; Mg; and manganeso, Mn). La concentración de nutrientes lixiviables en las cenizas fueron altos para los cationes $\mathrm{Ca}\left(>20 \mathrm{~g} \mathrm{~kg}^{-1}\right), \mathrm{K}\left(>4 \mathrm{~g} \mathrm{~kg}^{-1}\right)$, y $\mathrm{Mg}\left(>5 \mathrm{~g} \mathrm{~kg}^{-1}\right)$, lo que resultó en un alto $\mathrm{pH}$ en las cenizas (promedio \pm error estándar $=8.4 \pm 0.1$ ). Los cationes lixiviables fueron positivamente relacionados con la concentración total de cationes en las cenizas aunque las concentraciones de metales lixiviables (Fe; Mn; copper, Cu) fueron bajos a pesar de su alto contenido en las cenizas.

Conclusiones: Observamos diferencias en la producción y composición de cenizas que se correspondieron con variaciones en la cobertura de la vegetación, en la carga de combustibles, y en las tarjetas sensibles a la temperatura. La alta concentración de cationes lixiviables en las cenizas sugieren que quemas prescriptas repetidas pueden actuar decreciendo la disponibilidad de cationes en los suelos si los cationes son lixiviados a través del tiempo en suelos arenosos. En el caso de paisajes de pinos en tierras yermas, las quemas prescriptas, que reducen el stock de carbono y que a la vez producen una alta concentración de nutrientes lixiviables en sus cenizas, pueden contribuir a reducir el stock de nutrientes en el suelo y limitar el crecimiento de los árboles, ayudando de esa manera a mantener y restaurar ecosistemas amenazados en tierras yermas.

\section{Background}

Wildfire is a widespread natural process, and fossil evidence suggests that fire has shaped Earth's biomes since the emergence of land plants 440 million years ago (Glasspool et al. 2004). Ecologists consider fire a "global herbivore;" by consuming vegetation, fires maintain ecosystem structure and function and shape the global distribution of biomes (Bond and Keeley 2005). Fires may influence plant communities by killing small individuals in the understory, which reduces competition and provides greater resources for large individuals. Fire-adapted plants often require smoke, light gaps, or the removal of organic horizons by fire to germinate (Baxter et al. 1994; Taft 2003; Uys et al. 2004). Fires also modify resource availability. For instance, fire contributes to soil nutrient cycles by releasing nutrients stored in aboveground biomass to the soil matrix (Wan et al. 2001, Tuininga and Dighton 2004). In addition, fires alter the amount of organic matter present in soil and may result in the formation of hydrophobic residues, both of which influence water availability (Jiménez-Pinilla et al. 2016; Zheng et al. 2016). Despite these well-understood essential roles of fire, wildland fire exclusion and lack of prescribed burning have been a signature feature of the past century of land management and policy worldwide (Busenberg 2004; Fernandes et al. 2013; Ryan et al. 2013).

Although anthropogenic fire exclusion is meant to ensure human safety and protect natural resources, the resulting accumulation of surface fuels and changes to natural fire regimes in ecosystems that historically experienced frequent fires have contributed to a range of undesirable consequences such as catastrophic stand-replacing fires, and loss of vital habitat (Ryan et al. 2013). For example, in North America, up to $50 \%$ of tallgrass prairie species have been lost as a consequence of fire exclusion (Leach and Givnish 1996), and longleaf pine (Pinus palustris Mill.) savannas now occupy $<3 \%$ of their historical range in the southeastern United States due to logging, farming, and fire exclusion (Noss et al. 1995). As land managers become aware of the connection between 
fire exclusion and habitat loss, prescribed fire becomes an increasingly important tool for restoring ecosystem composition, structure, and function. One example of a globally imperiled habitat type (i.e., fewer than 100 communities globally) under active prescribed fire management is jack pine (Pinus banksiana Lamb.) barrens of the Great Lakes region, USA (Wisconsin DNR 2015).

Great Lakes region pine barrens are savanna communities with a scattered jack pine or red pine (Pinus resinosa Aiton.) overstory and a characteristic heath understory (Curtis 1959). Fire is thought to be the primary environmental variable that maintains open barrens habitats, while sandy glacial outwash soils and local topography also contribute (Vora 1993). Historically (from 1660 to 1925), a fire return interval of 8 to 15 years maintained northwest Wisconsin's Moquah Barrens, but US fire exclusion policy over the past $\sim 90$ years has increased the mean fire return interval to over 43 years (Guyette et al. 2016). Barrens now cover less than $0.5 \%$ of their original extent due to a combination of fire exclusion, succession, and land use change following European settlement (USDA Forest Service 2013; Wisconsin DNR 2015). Because barrens soils are sandy, they tend to leach nutrients and have poor fertility. In the absence of fire, woody species are able to invade barrens, which may result in increases in soil nutrients and water holding capacity (Vogl 1970).

Edaphic changes associated with fire-produced, or pyrogenic, nutrient sources (i.e., ash) may influence plant community structure and function in fire-prone ecosystems. The quantity and quality of pyrogenic nutrient sources depend on the type and amount of fuel burned and extent of combustion (Bodi et al. 2014). Ash, defined as the particulate residue formed by pyrolysis and combustion of wildland fuels and subsequently deposited on land surfaces, may influence ecosystem changes-such as encroachment by woody species in the historically grass- and forb-dominated barrens ecosystem-via its effects on soil microbial activity, carbon pools, $\mathrm{pH}$, nutrients, texture, and hydrological properties (Bodi et al. 2014; Tuininga \& Dighton 2004). The ash layer includes residues spanning a range of combustion completeness, ranging from charred organic material (black ash) to mineral-rich white ash (Bodi et al. 2014). White ash is especially concentrated with mineral elements important for plant nutrition (Pereira et al. 2012; Campos et al. 2016), but phytotoxic elements like chromium, cadmium, and lead, may also be present in high concentrations (Liodakis et al. 2009). The release of chemical elements from ash is dependent upon fire severity, fuel source, underlying soil properties, and element-specific chemistry (Pereira et al. 2012; Escudey et al. 2015).

It is important to understand the in situ drivers of variation in ash production and composition since laboratory-generated combustion does not accurately mimic field combustion conditions or composition of wildland fire ash (Bodí et al. 2011). Because ash is a pyrogenic nutrient source that may influence the soils and plant communities of fire-dependent landscapes, we leveraged an ongoing barrens restoration study using prescribed fire to answer the following questions: 1) Which burn factors affect the amount and composition of ash produced during prescribed fire? 2) What proportion of the nutrients in ash samples is leachable? and 3) What role might nutrient inputs from ash play in the context of pine barrens restoration? To address these questions, we collected and analyzed ash layer samples following two large-scale prescribed burns ( 1200 ha total) in the Moquah Barrens of northwest Wisconsin, USA, in May 2016. We expected ash production and composition to be influenced by burn conditions and vegetation cover because plant communities differ in their fuel loads, flammability, and leaf chemistry. Specifically, we hypothesized that sites with greater amounts of fuels would produce greater ash loads, and that ash chemical profiles would be affected by vegetation type and by the temperatures of ash and pyrolizing fuel particles during the fire (as indicated by maximum paint tag temperatures). Furthermore, we predicted that leachable nutrient concentrations would be related to total ash nutrient concentrations and element-specific conditions for solubility, such as $\mathrm{pH}$. Finally, we considered how the observed variation in ash loads and ash chemical compositions might influence soil nutrient loads, specifically in the context of reducing nutrient stocks to support the persistence and expansion of pine barrens.

\section{Methods}

\section{Study area}

Study sites were located in the Moquah Barrens of the Northwest Sands ecological landscape in northwest Wisconsin, on the Chequamegon-Nicolet National Forest, USA (Fig. 1). Mean annual temperature in the Northwest Sands is $5.2{ }^{\circ} \mathrm{C}$ (mean January minimum $=-18.9^{\circ} \mathrm{C}$, mean August maximum $=26.9{ }^{\circ} \mathrm{C}$ ), and mean annual precipitation is $80 \mathrm{~cm}$. Annual snowfall averages $155 \mathrm{~cm}$, and the typical growing season length is 121 days (Wisconsin DNR 2015). Soils are classified as slightly to strongly acidic ( $\mathrm{pH}=5.1$ to 6.5$)$ spodosols with a depth of 15 to $25 \mathrm{~cm}$ to the spodic horizon under NRCS Soil Taxonomy (Soil Survey Staff 1999). Soils consist of well-drained sands and sandy loams of glacial outwash origin, with a low water holding capacity and low cation exchange capacity (Tweiten et al. 2015). This landscape consists of a mosaic of hardwood forest, pine woodland, shrubland, and grasslands (Curtis 1959). In this study, deciduous forest was defined as closed-canopy forest with trees at least $12 \mathrm{~cm}$ diameter at breast height (DBH) dominated by oaks 

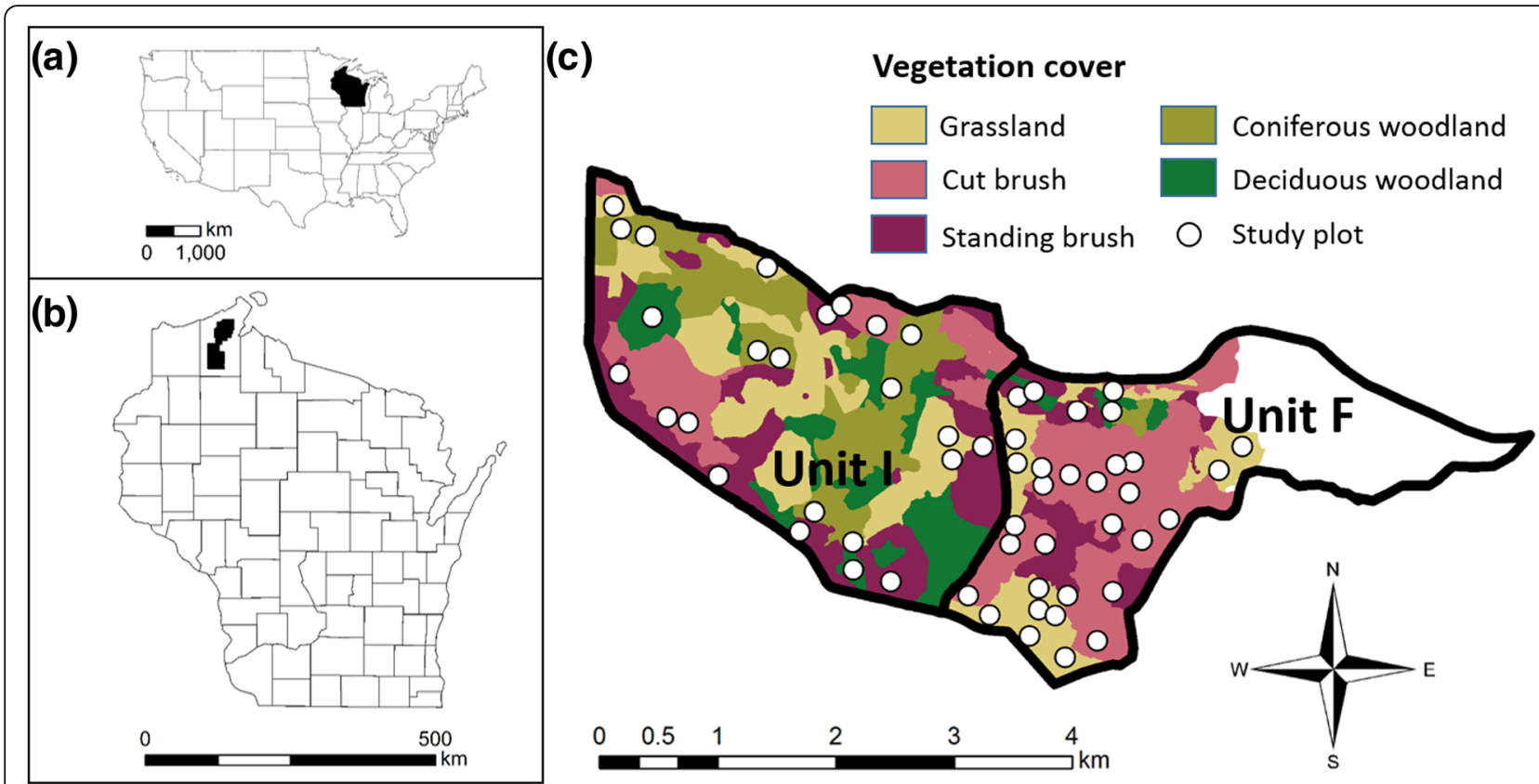

Fig. 1 The Moquah Barrens are located in northern Wisconsin, USA (a), within the Washburn Ranger District of the Chequamenon-Nicolet National Forest (b). The 56 study plots span two burn units, F and I, which were burned in May 2016 (c). Colors indicate vegetation cover type derived from stand inventory maps from the Chequamegon-Nicolet National Forest (CNNF). The unfilled eastern portion of unit $F$ was excluded from the 2016 burns

(Quercus rubra L., Q. ellipsoidalis E.J. Hill), aspens (Populus tremuloides Michx., P. grandidentata Michx.), and red maple (Acer rubrum L.). Pine woodland was defined as recently thinned (i.e., within the last 5 to10 years) pine plantation (red pine, Pinus resinosa Aiton.; jack pine, $P$. banksiana Lamb.; and white pine, P. strobus L.) with semi-open canopy and a target range in tree basal area of 7 to $14 \mathrm{~m}^{2} \mathrm{ha}^{-1}$. The surface vegetation layer in these forest and woodland systems was dominated by a combination of bracken fern (Pteridium aquilinum [L.] Kuhn var. litiusculum [Desv.]), lowbush blueberry (Vaccinium angustifolium Aiton.) and various herbaceous species. Shrubland sites were defined as having $>50 \%$ cover by woody shrubs and tree saplings (Q. rubra, A. rubrum, Amelanchier laevis Wiegamd, Corylus cornuta Marshall, C. americana Walter, Salix humilis Marshall, and others) and with dominant stem $\mathrm{DBH}<12 \mathrm{~cm}$, excluding low shrubs characteristic of the pine barrens ecosystem (e.g., Vaccinium L. spp.; and sweetfern, Comptonia perengrina [L.] J.M. Coult.). Grassland sites included a spectrum of savanna to grassland with tree basal area $7 \mathrm{~m}^{2} \mathrm{ha}^{-1},<30 \%$ shrub cover, and surface vegetation layer dominated by low shrubs (Vaccinium spp. and Comptonia peregrina), grasses, sedges, and forbs. Historically dominant red, white, and jack pine have declined while oak and aspen have increased at former pine sites, and forest canopy closure has also increased since the mid-nineteenth century (Radeloff et al. 1999).

\section{Experimental design and instrumentation}

Experimental plots were installed following modified FIREMON protocols (Lutes et al. 2006) at 56 locations throughout two adjacent burn units managed by the Chequamegon-Nicolet National Forest. Plots were $20 \mathrm{~m}$ in radius (area $=1256.6 \mathrm{~m}^{2}$ ) and contained $1 \mathrm{~m}^{2}$ quadrats utilized for various monitoring purposes. Plots spanned four vegetation cover types, as defined above. We manipulated fuel loads among these cover types to maximize among-plot variation in fire behavior and soil heating during the prescribed burns. Shrubland sites were further divided based on mechanical cutting: woody fuels were either left standing, cut and left on site (Fig. 2b), or cut and removed. A subset of grasslands $(n=4)$ and pine woodlands $(n=4)$ served as fuel addition plots, to which cut brush was added to approximately $2.2 \mathrm{~kg} \mathrm{~m}^{-2}$. Deciduous forest plots were not subjected to fuel addition. An overview of design factors and replication is provided in Table 1.

We created temperature indicators by applying temperature-sensitive Tempilaq paint (LA-CO Industries Inc., Elk Grove Village, Illinois, USA) to 0.635-centimeter-thick aluminum tags ("racetrack" tags, product number 36814313; Ben Meadows, Janesville, Wisconsin, USA). We applied eight unique temperature-sensitive Tempilaq paints with melt temperatures ranging from $79^{\circ} \mathrm{C}$ to $426{ }^{\circ} \mathrm{C}$ to each paint tag. We installed paint tags at the center of each quadrat, co-located with the ash sampling 


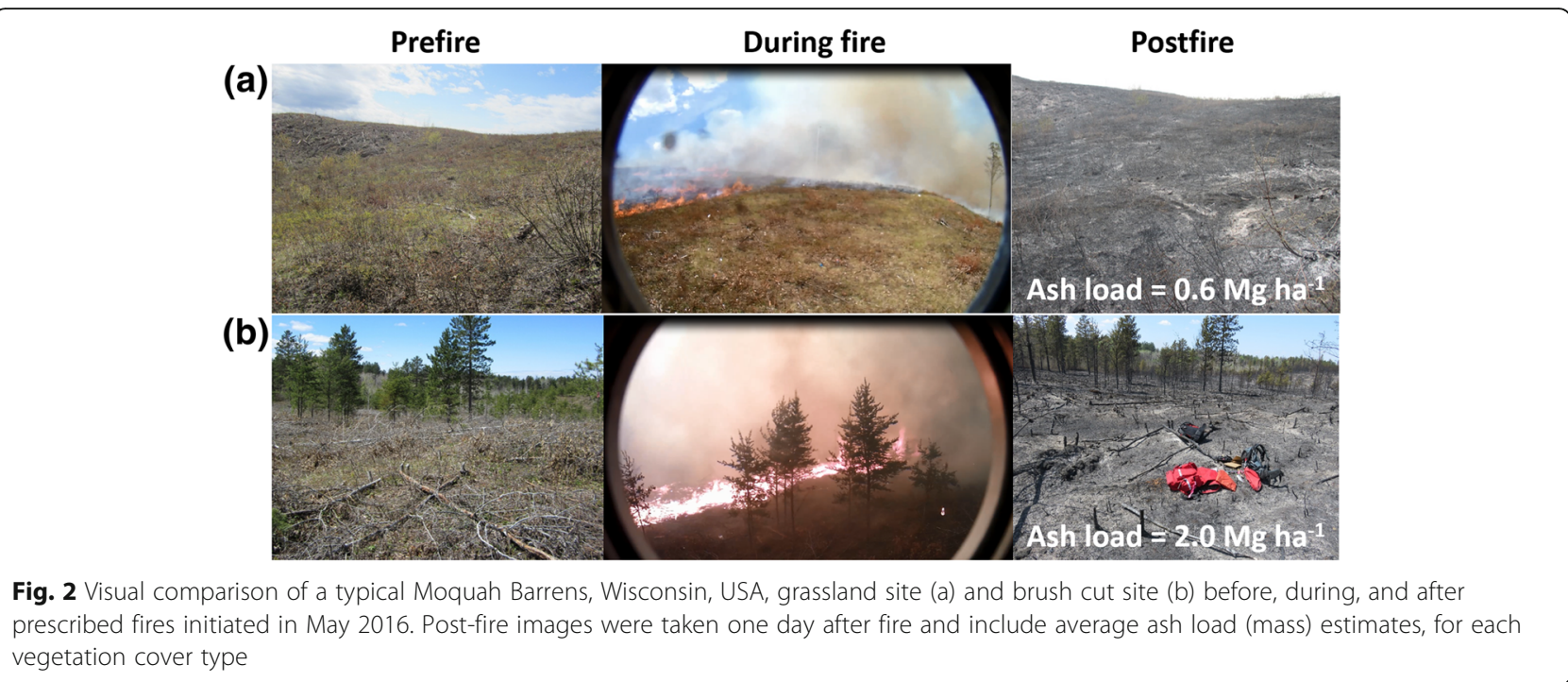

location, at both the litter surface and hanging at $25 \mathrm{~cm}$ above the litter surface using steel tree tag stakes, one day before the prescribed burn in each unit.

\section{Prescribed burns}

The Chequamegon-Nicolet National Forest increased prescribed burn efforts in 2008, with a prescribed-burn schedule rotating among several management units ("burn blocks"), each 200 to 800 ha. Burn units F and I (Fig. 1) were burned successively on 19 and 20 May 2016, respectively, for this study. Unit F was ignited at 1057 hours and took $8.5 \mathrm{~h}$ of ignition time to complete, and Unit I was ignited at 1012 hours and took $9.5 \mathrm{~h}$ to complete. Unit $\mathrm{F}$ was further along in restoration efforts and was last burned in 2013. Unit I, which was predominately conifer plantation, was in an earlier restoration stage. About half of Unit I had not been burned for

Table 1 Summary of the distribution of sampling sites in the Moquah Barrens (Chequamegon-Nicolet National Forest), Wisconsin, USA, included in this study. Ash samples were collected in May of 2016 following two successive prescribed burns. Numbers indicate the number of study plots for each combination of historical and current vegetation state. Historical state is based on a USDA 1951 Timber Survey, and current vegetation state is based on a 2016 Forest Service survey. Letters in parentheses indicate fuel treatments: $A=$ addition, $C=$ cut brush, $C \& R=$ cut and remove

\begin{tabular}{lccc}
\hline \multirow{2}{*}{$\begin{array}{c}\text { Historic State } \\
\text { (circa 1951) }\end{array}$} & \multicolumn{3}{c}{ Current State } \\
\cline { 2 - 4 } & Forest & Shrubland/Brush & Grassland \\
\hline Pine plantation & $5^{*}+3(\mathrm{~A})$ & $4+4(\mathrm{C})+4(\mathrm{C} \& \mathrm{R})$ & $4+4(\mathrm{~A})$ \\
Deciduous Forest & 4 & $4+4(\mathrm{C})+4(\mathrm{C} \& \mathrm{R})$ & $4+4(\mathrm{~A})$ \\
Grassland & & & 4 \\
\hline
\end{tabular}

*Sample sizes without fuel treatment codes indicate that fuels were not manipulated (i.e., ambient conditions)
$>50$ years, and the remaining half was last burned between 2001 and 2007. At the time of the 2016 burns, 10-hour woody fuel moisture was approximately $10 \%$, and duff moisture was approximately $45 \%$.

\section{Field data collection}

Ash sampling was conducted as soon as the study sites were accessible, within 24 to $48 \mathrm{~h}$ post fire. Ash is a highly mobile substance subject to rapid change; all samples in this study were collected prior to precipitation events to minimize dilution, redistribution, and other disturbances that may result in changes to ash physical and chemical properties. We collected the entire ash layer, ranging along the spectrum of fire-produced residue from charred black material to white mineral ash, as per Bodi et al. (2014), omitting large pieces of charred material $>1 \mathrm{~cm}^{3}$. Ash was collected in macroplot quadrats 1 through 4, from within an anchored $30 \mathrm{~cm}$ diameter sampling frame installed at quadrat center. The depth of the ash layer was measured in each cardinal direction along the interior edge of the sampling frame and the four measurements were averaged.

\section{Paint tag temperatures and calculations}

Aluminum tags that melted were assigned a melt temperature of $661{ }^{\circ} \mathrm{C}$, which is near the upper end of the range in melt temperatures reported for the aluminum alloy used to make the tags (Aluminum alloy 1100-O; www.matweb.com, accessed 1 June 2018). Paint tag temperatures were additionally assigned to ranked temperature categories based on temperature thresholds identified in Balfour and Woods (2013). Categories were: no melt (temperatures below $79.4{ }^{\circ} \mathrm{C}$ ), low (samples with melt from 79 to $253{ }^{\circ} \mathrm{C}$; minimum charring occurs), moderate (melt from 287 to $426{ }^{\circ} \mathrm{C}$; combustion begins), and high (melt $\geq 660{ }^{\circ} \mathrm{C}$; carbonate 
formation occurs). Although paint tags record only the maximum temperature reached, and there are gaps between the melt temperatures of thermocolor paints, they are cost effective and convenient for extrapolating data from more precise monitoring tools to a finer spatial scale. To provide a basis for comparison with other studies (see Bova and Dickinson 2008), we used co-located thermocouple data and a calibration equation to report our paint tag results as fuel consumption in $\mathrm{Mg} \mathrm{ha}^{-1}$ (Additional file 1: S1). Our fuel consumption estimates are best thought of as calibrated fuel consumption, hereafter termed fuel consumption. Paint tags do not undergo pyrolysis and otherwise have very different heat budgets than fuel particles and surface ash. Although we have no data on the mean and distribution of the temperatures of ash and pyrolyzing fuels, it is likely that paint tag temperatures correlate with mean temperatures experienced by pyrolyzing fuels and ash in fires. As such, we reported paint tag temperatures in relation to nutrient concentrations in ash with the expectation that nitrogen, which volatilizes at biomass pyrolysis temperatures (Raison 1979), should have the lowest concentrations when paint tag temperatures were greatest. We also used thermocouple data to estimate fireline intensity, based on the maximum rate of thermocouple temperature increase described in Equation 14 in Bova and Dickinson (2008).

\section{Laboratory analysis}

Prior to nutrient extraction procedures, ash samples were air dried, weighed, and pulverized using a SPEX 8000D Mill (SPEX Sample Prep LLC, Metuchen, New Jersey, USA). Total carbon (C) and nitrogen (N) concentrations were analyzed using a Costech dry combustion elemental analyzer (Costech Analytical Technologies Inc., Valencia, California, USA). Total elemental concentrations of potassium $(\mathrm{K})$, calcium $(\mathrm{Ca})$, magnesium $(\mathrm{Mg})$, manganese $(\mathrm{Mn})$, iron $(\mathrm{Fe})$, and copper $(\mathrm{Cu})$ were estimated following a microwave digestion of $0.5 \mathrm{~g}$ ash in $9 \mathrm{ml}$ of nitric acid $\left(\mathrm{HNO}_{3}\right)$ and $3 \mathrm{ml}$ of $37 \%$ hydrochloric acid $(\mathrm{HCl})$ and hereafter referred to as total extractable elements (TEE; Santín et al. 2015). To determine concentrations of leachable element (i.e., plant-available; LE) concentrations in ash, we performed a water extraction using a 1:20 ratio (1 part ash in 20 parts leachate) of ash sample in deionized water (Hageman 2007), with slurries immediately measured in triplicate for pH (Benchtop 700 Series; Oakton Instruments, Vernon Hills, Illinois, USA), filtered through a $0.45 \mu \mathrm{m}$ filter, and frozen until elemental analysis. Phosphorous was extracted via the Olsen method and measured colorimetrically (Olsen et al. 1954) using a Brinkman PC 950 probe (STH Company, Cocoa Beach, Florida, USA). Calcium, $\mathrm{Mg}$, and $\mathrm{K}$ were extracted using $20 \mathrm{ml}$ of $1 \mathrm{~N}$ ammonium acetate $\left(\mathrm{NH}_{4} \mathrm{CH}_{3} \mathrm{CO}_{2}\right)$ and measured by flame photometry (for $\mathrm{Ca}, \mathrm{K}$ ), or colorimetrically (for $\mathrm{Mg}$ ). The remaining micronutrient concentrations $(\mathrm{Mn}, \mathrm{Fe}, \mathrm{Cu})$ were analyzed by atomic adsorption spectrophotometry (AAnalyst 400; PerkinElmer, Inc. Waltham, Massachusetts, USA). All elemental analysis was performed at the Michigan State University Soil and Plant Nutrient Laboratory, and values were reported per unit mass of ash (g element per $\mathrm{kg}$ ash).

Pyrogenic carbon $(\mathrm{PyC})$ content in ash was estimated using a weak nitric acid digestion, which removes organic material and assumes that residual $\mathrm{C}$, most resistant to oxidation, represents charcoal C (Kurth et al. 2006; Maestrini and Miesel 2017). Briefly, $100 \mathrm{mg}$ of ash was diluted with quartz sand to a total sample weight of $1.0 \mathrm{~g}$. Next, $20 \mathrm{~mL}$ of $1 \mathrm{M}$ nitric acid and $10 \mathrm{~mL}$ of $30 \%$ hydrogen peroxide were added to each sample. Samples were shaken, then heated on a block digester (SEAL Analytical Digestion Block; SEAL Analytical Inc., Southampton, England, United Kingdom) to $100{ }^{\circ} \mathrm{C}$ for $16 \mathrm{~h}$. The solutions were cooled and filtered, and the amount of $\mathrm{C}$ present after digestion was measured via dry combustion as described above, and is considered PyC.

\section{Data analysis}

To understand which factors influence the amount of ash produced during prescribed burns, we tested for relationships between ash mass (response variable) and categorical burn factors (i.e., vegetation cover types, paint tag temperature classes, and woody fuel addition or removal) as predictor variables using Type I ANOVAs to compare three or more treatment groups. $T$ tests were applied for the pairwise comparison of ash mass between ambient fuel conditions and fuel addition treatments at conifer and grassland plots. Similarly, burn factors were tested as predictors of ash nutrient concentrations and nutrient loads (concentration scaled by mass) using ANOVAs and $t$ tests for the comparison of $\geq 3$ or 2 treatment groups, respectively.

For comparisons among vegetation cover types, we excluded samples collected where fuels were manipulated (i.e., addition or removal) to focus on ambient variation and avoid confounding effects. Fuel treatments were analyzed separately within each cover type. Post hoc Tukey's tests were used for pairwise comparisons of treatment means when ANOVAs identified significant differences among groups. We used ordinary least squares linear regression to explore relationships between total nutrient concentrations and easily extractable concentrations. Differences in ash chemical profiles were visualized using radar plots using the $R$ package fmsb. Finally, we calculated nutrient stocks by multiplying the concentration $\left(\mathrm{ppm}=\mathrm{mg} \mathrm{kg}^{-1}\right)$ by ash load represented in each ash sample location $\left(\mathrm{g} \mathrm{m}^{-2}\right)$, scaled to $\mathrm{kg} \mathrm{ha}^{-1}$ to understand the relationships between burn factors and nutrient stocks for each specific 
element. All statistical analyses were performed in R, version 3.4.2 ( $R$ Development Core Team 2014).

\section{Results}

\section{Fire behavior}

We observed a wide range of variation in fire behavior and soil heating throughout the two burn units (Fig. 3). Mean fireline intensity was $663 \mathrm{~kW} \mathrm{~m}{ }^{-1}$ (minimum = $115 \mathrm{~kW} \mathrm{~m}{ }^{-1}$, maximum $=1472 \mathrm{~kW} \mathrm{~m}^{-1}$ ), and soil temperature at the duff-soil interface rose by an average $51{ }^{\circ} \mathrm{C}$ (minimum $=17{ }^{\circ} \mathrm{C}$, maximum $=372{ }^{\circ} \mathrm{C}$ ). Mean fuel consumption was $15.7 \mathrm{Mg} \mathrm{ha}^{-1}$ (minimum = $0.16 \mathrm{Mg} \mathrm{ha}^{-1}$, maximum $=40 \mathrm{Mg} \mathrm{ha}^{-1}$ ) and fire decreased the duff layer thickness by an average of $0.5 \mathrm{~cm}$. Paint tags at the litter surface reached consistently higher temperatures (median $=343^{\circ} \mathrm{C}$ ) than those installed at $25 \mathrm{~cm}$ above the litter surface (median = $253{ }^{\circ} \mathrm{C}$; Fig. 3b). Maximum temperatures reached by paint tags at the litter surface were more closely related to fuel consumption than those at $25 \mathrm{~cm}$ and, as such, we reported fuel consumption estimated from litter surface paint tag temperatures (Additional file 1: S1). At plots with ambient fuel conditions (i.e., no addition or removal of fuel), paint tag temperatures at cut brush sites were greater than those of all other vegetation cover types (Fig. 3c). Fuel addition resulted in significant increases in paint tag temperatures and consumption at grassland plots $(t=3.4, P=0.001$, and $t=-4.0$, $P<0.05$, respectively; Fig. $4 \mathrm{a}$ and $\mathrm{b})$, but not at pine plots $(P=>0.05$, data not shown).

\section{Ash production}

The ash layer following prescribed burns ranged in depth from 0.0 to $2.6 \mathrm{~cm}$ (mean $=0.9 \mathrm{~cm}$ ), and the average ash load for the 131 samples analyzed was $2.0 \mathrm{Mg} \mathrm{ha}^{-1}$ (maxinmum $=10.2 \mathrm{Mg} \mathrm{ha}^{-1}$ ). Ash depth was positively related to ash mass $(P<0.01)$, but the strength of this relationship was low $\left(R^{2}=0.13\right)$. Ash loads displayed a trend of increased ash produced at higher paint tag temperatures and calibrated fuel consumption, although a post hoc Tukey's test revealed that only moderate and high temperatures were significantly different (difference $=1.3 \mathrm{Mg} \mathrm{ha}^{-1}, P=0.02$; Fig. 5a). Ash loads were $12.5 \%$ of consumed fuel loads on average ( minimum $=5.3 \%$, maximum $=27.4 \%$, and consumption and ash load were positively related $\left(F=9.3, \mathrm{R}^{2}=0.34, P\right.$ $<0.01$ ). Among samples with ambient fuel loads, conifer plots had mean ash loads that were two to three times greater than those of all other vegetation cover types (mean conifer ash load $=4.1 \mathrm{Mg} \mathrm{ha}^{-1}$, all Tukey's pairwise $P<0.05)$. However, ash loads among conifer plots were also the most variable (minimum $=0.7 \mathrm{Mg} \mathrm{ha}^{-1}$, maximum $=10.2 \mathrm{Mg} \mathrm{ha}^{-1}$ ). Mechanical brush cutting resulted in an $89 \%$ increased ash load relative to ambient shrublands with standing brush $(P<0.05, \quad t=-2.1$; Fig. 5b). Similarly, grassland plots that had woody fuels added had ash loads that were $64 \%$ greater than those of ambient grasslands without added fuels $(P=0.01, t=$ -2.6 ; Fig. 5c). There was, however, no significant difference in ash loads between ambient conifer woodlands and conifer woodlands with added woody fuels.

\section{Total and leachable ash nutrient concentrations}

Total post-fire carbon $(\mathrm{C})$ concentration in ash ranged from 6.6 to $61.7 \% \quad($ mean $=41.1 \%)$ and displayed a non-significant trend of decreasing $\mathrm{C}$ with increasing ranked paint tag temperature categories $(P>0.10$ for all pairwise comparisons). Pyrogenic carbon (PyC) concentration was low, but varied by a factor similar to that of total $\mathrm{C}$ (minimum $=0.07 \%$, maximum $=1.04 \%$, mean $=$ $0.43 \%$ ). Of the nutrients analyzed, we noted especially high total extractable element (TEE) concentrations of $\mathrm{N}$ $(\mu=1.53 \%), \mathrm{Ca} \quad\left(\mu=21.3 \mathrm{~g} \mathrm{~kg}^{-1}\right.$ ash $)$, and $\mathrm{Fe}(\mu=$ $7.3 \mathrm{~g} \mathrm{~kg}^{-1}$ ash), while total extractable $\mathrm{Cu}$ concentrations were consistently low $\left(\mu=0.0027 \mathrm{~g} \mathrm{~kg}^{-1}\right.$ ash). $\mathrm{K}, \mathrm{Mg}$, and $\mathrm{Mn}$ TEE concentrations were significantly different among vegetation cover types (see Table 2 for mean TEE concentration by vegetation cover for all nutrients). Similarly, differences between TEE concentrations were observed among paint tag temperature groups (Additional file 1: Table S2). Ash nitrogen concentrations, for instance, were more than 2.5 times as high in the low temperature group than in the high temperature group.

Leachable element (LE) concentrations in ash were greatest for $\mathrm{Ca}$ and $\mathrm{K}\left(\mu \mathrm{Ca}=0.75 \mathrm{~g} \mathrm{~kg}^{-1}, \mu \mathrm{K}=\right.$ $0.60 \mathrm{~g} \mathrm{~kg}^{-1}$ ), and were often below the limit of detection for $\mathrm{Fe}$ and $\mathrm{Cu}\left(\mu=6.6 \mathrm{e}^{-4} \mathrm{~g} \mathrm{~kg}^{-1}, 8.7 \mathrm{e}^{-4} \mathrm{~g} \mathrm{~kg}^{-1}\right)$. Cut brush sites produced ash that had significantly greater LE cation concentrations than other vegetation cover: LE Ca was more than two times greater than in ash from deciduous, shrubland, and grassland sites; LE Mg was significantly greater than ash from grassland and deciduous forest sites; and LE K was 170\% greater in cut brush ash than ash collected from conifer sites (Additional file 1: Table S3; all $P<0.05$, Tukey multiple comparisons). More than $70 \%$ of the observed variation in LE K concentrations (adj. $\mathrm{R}^{2}=0.72, F=242.5$, slope $=0.29$, $P<0.01$ ) was explained by TEE concentrations (Fig. 6). LE Ca (adj. $\mathrm{R}^{2}=0.28, F=37.4$, slope $=0.02, P<0.01$ ), and LE Mg (adj. $\mathrm{R}^{2}=0.18, F=242.5$, slope $=0.04, P<0.01$ ) were positively related to TEE values, but with relatively poor explanation of variance. No statistically significant relationships were observed between LE and TEE concentrations of $\mathrm{P}$ or metal species $(\mathrm{Mn}, \mathrm{Cu}, \mathrm{Fe})$. Ash $\mathrm{pH}$ was a function of the sum of cation concentration $(\mathrm{K}+$ $\mathrm{Ca}+\mathrm{Mg}$ ), with TEE providing a better prediction of $\mathrm{pH}$ than LE (Fig. 6d; TEE adj. $\mathrm{R}^{2}=0.48, F=86.2, P<0.01$; LE adj. $\mathrm{R}^{2}=0.44, P<0.01, F=97.8$ ). 


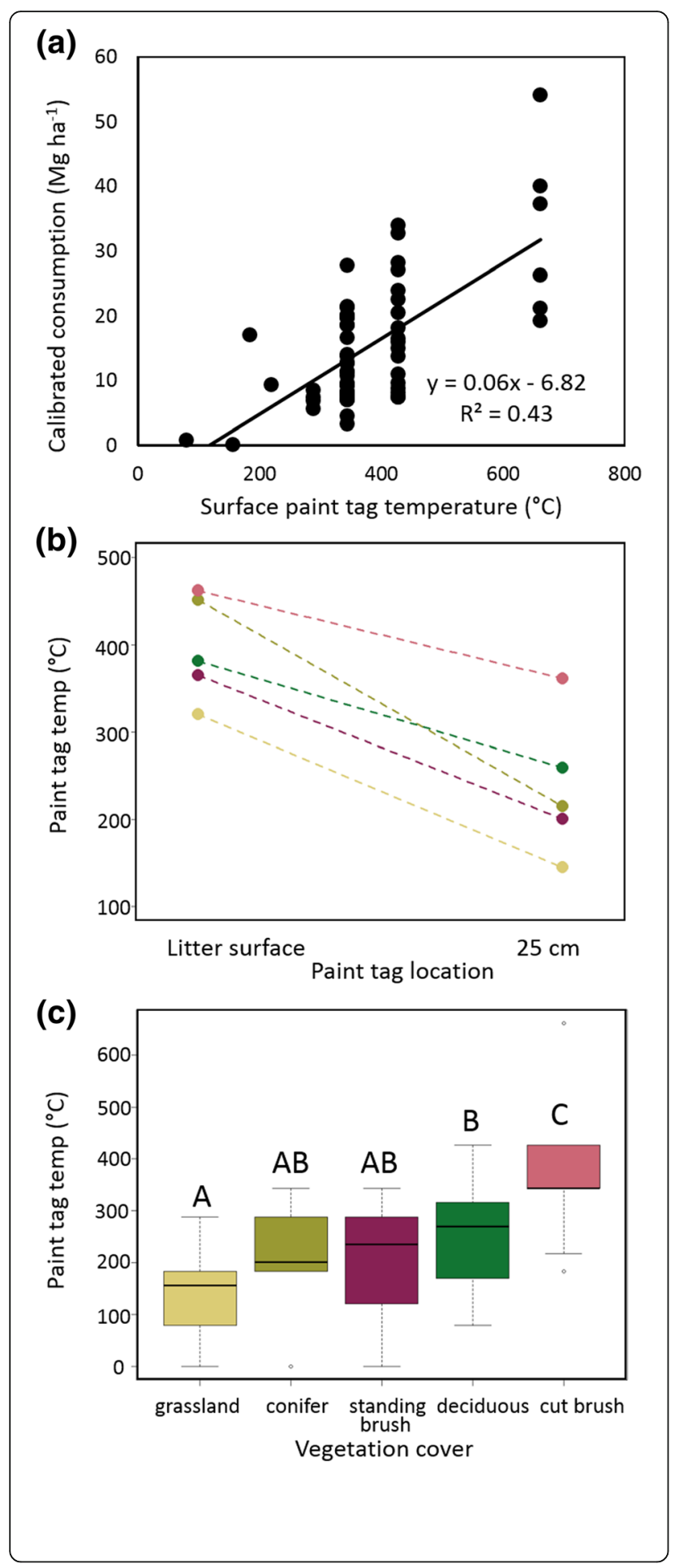

Fig. 3 Relationships among maximum paint tag temperature, fuel consumption, and vegetation cover for Moquah Barrens, Wisconsin, USA, study sites, burned in May 2016. Temperature (temp) estimated by paint tags installed at the soil surface explained $43 \%$ of variation in calibrated fuel consumption (a), and paint tags installed at the soil surface reached higher temperatures than those elevated to $25 \mathrm{~cm}$ aboveground (b). Elevated paint tag temperatures also varied with vegetation cover: paint tags at cut brush sites recorded higher temperatures than all other cover types, and grasslands had lower temperatures than deciduous forest (c). Colors correspond to vegetation cover in map (Fig. 1), and letters indicate statistically different groups identified by pairwise comparisons (Tukey's).

Consumption estimates are derived from a thick thermocouple probe co-located with paint tags as described in Additional file 1: S1

\section{Ash nutrient stocks}

Vegetation cover was related to variation in ash $\mathrm{C}, \mathrm{PyC}$, $\mathrm{K}, \mathrm{Mg}, \mathrm{Mn}, \mathrm{Fe}$, and $\mathrm{Cu}$ stocks after excluding plots with fuel manipulations from analysis. Despite the relatively poor quality (i.e., low nutrient status) of ash generated in conifer woodlands (Fig. 7a), ash nutrient stocks were often highest in conifer woodlands due to greater overall production of ash (i.e., ash mass; Fig. 7b). Ash $\mathrm{C}$ and PyC stocks at conifer plots were on average more than double the ash $\mathrm{C}$ and PyC stocks of all other vegetation cover types. Similarly, mean ash stocks of $\mathrm{K}, \mathrm{Mg}$, Fe, and $\mathrm{Cu}$ at conifer sites were typically double those of other vegetation types (Fig. 7). Mn stocks were, on average, greatest at cut brush sites $\left(\mu=7.5 \mathrm{~kg} \mathrm{ha}^{-1}\right)$, where they were more than four times greater than those of grassland sites $\left(\mu=1.7 \mathrm{~kg} \mathrm{ha}^{-1}\right)$. Grassland and shrubland plots produced consistently low stocks of $\mathrm{C}$, PyC, cations $(\mathrm{Ca}, \mathrm{Mg}, \mathrm{K})$, and metals $(\mathrm{Mn}, \mathrm{Fe}$, and $\mathrm{Cu})$. Although ranked paint tag categories were strong predictors of some ash element concentrations, ash nutrient stocks (N, P, cations, C species, and metals) could not be predicted using paint tag temperatures (ANOVA $P>0.05$ for all elements).

\section{Discussion}

Production and composition of ash from prescribed burns Paint tag and woody fuel consumption data indicated that vegetation cover type and woody fuel addition treatments altered prescribed burn conditions throughout the Moquah landscape. Paint tags located at the litter surface were better predictors of consumption and ash mass than tags elevated to $25 \mathrm{~cm}$, suggesting that the heat budgets of litter paint tags better reflect combustion conditions within the fuel bed, whereas elevated tags are more responsive to flame characteristics such as fireline intensity. We observed a positive relationship between paint tag temperatures and both calibrated fuel consumption and ash production, with an average ash yield of $12.5 \%$ of pre-fire fuels and average ash load of 2 to $5 \mathrm{Mg} \mathrm{ha}^{-1}$. This 

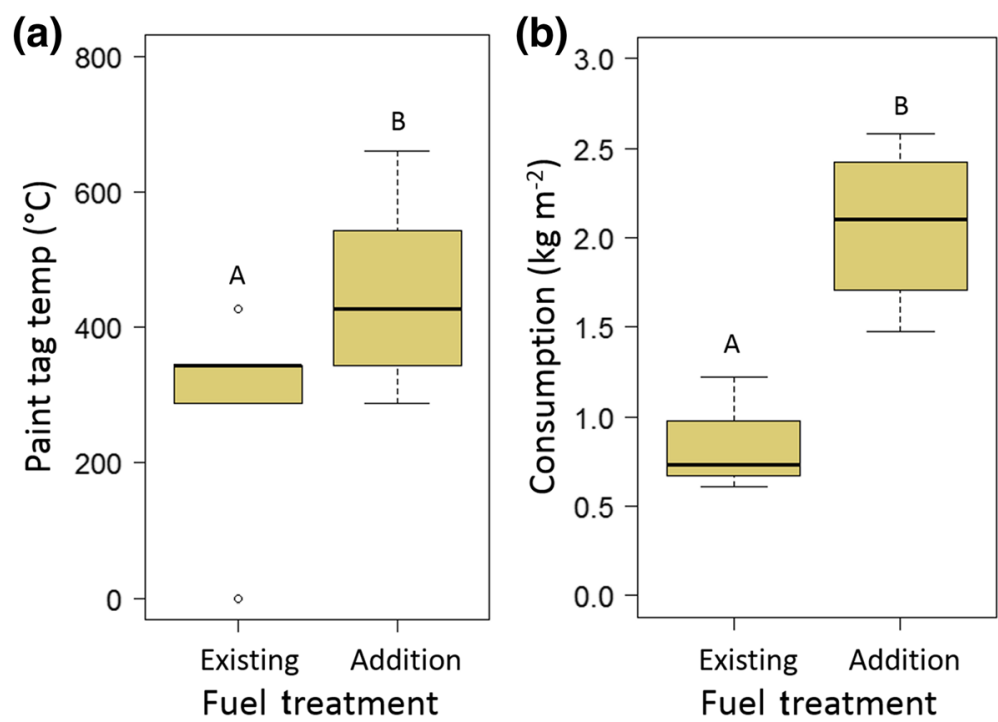

Fig. 4 The addition of woody fuels to Moquah Barrens, Wisconsin, USA, grasslands sites, burned in May 2016, resulted in (a) increased paint tag temperatures (temp) relative to grassland plots with existing fuel loads and (b) increased fuel consumption relative to plots with existing fuel loads. Letters indicate statistically different groups identified by Tukey's pairwise comparisons

is much lower than values of 5 to $35 \mathrm{Mg} \mathrm{ha}^{-1}$ estimated for wildfires in Australian eucalypt forest (Santín et al. 2015) and may be explained by differences in fire severity and fuel types between studies. Ash production estimates in Santín et al. (2015) were for wildfires that were typically of extreme severity (all stems $\leq 1 \mathrm{~cm}$ DBH consumed), whereas prescribed fires in Moquah were typically considered only "lightly burned," according to the National Park Service burn severity coding matrix (NPS 2003). Furthermore, the eucalypt forest had relatively homogenous fuel loads of 25 to $30 \mathrm{Mg} \mathrm{ha}^{-1}$ (estimated for ground, understory, bark, and canopy fuels $<1 \mathrm{~cm}$ diameter) with a dense shrub understory (Banksia L.f., Leptospermum J.R. Forst. \& G. Forst., Acacia Mill., and Petrophile R.Br. ex Knight species) that had not burned for 17 years. In contrast, Moquah fuel loads were more variable and generally lower $\left(\right.$ mean $=9.8 \mathrm{Mg} \mathrm{ha}^{-1}$, median $=6.2 \mathrm{Mg} \mathrm{ha}^{-1}$, maximum $=52.4 \mathrm{Mg} \mathrm{ha}^{-1}$ ), as much of the Moquah Barrens landscape is under active management with prescribed fires. A more recent study of prescribed fire in an Australian eucalypt forest with lower fuel loads (15 to $25 \mathrm{Mg} \mathrm{ha}{ }^{-1}$ ) created an average ash load of $6.3 \mathrm{Mg} \mathrm{ha}^{-1}$, similar to the values observed in our study (Santín et al. 2018). Furthermore, we observed a trend of greatest ash production in conifer woodlands and the least production at shrubland sites, which is likely driven by differences in surface fuel loads, with the conifer woodlands supporting a deeper forest floor and more residual litter after fire than shrubland sites. Our fuel manipulation plots further support this pattern: cut brush plots (with cut fuels left on site) produced more ash than shrubland plots, and grassland plots with woody fuels added produced more ash than grassland plots with ambient fuel loads. Finally, mineral and organic soils may also contribute to ash layer, but these contributions are expected to be minimal in Moquah soils, which are sandy and poor in organic matter.

Temperature thresholds are known to affect ash structure and chemical composition, because each component of organic matter volatilizes or undergoes chemical transformation at specific temperatures (Ubeda et al. 2009). As temperatures in furnaces approach $450{ }^{\circ} \mathrm{C}$, greater losses of organic carbon are observed, and the $\mathrm{pH}$ of ash extracts increases as the elements in ash are solubilized (Hogue and Inglett 2012; Balfour and Woods 2013). Although it is difficult to compare results from controlled, closed environments of furnaces with results from open combustion such as occurs in wildland fires, we suspect that, when paint tag temperatures, fuel consumption, and fire energy (in MJ ha ${ }^{-1}$, which scales with consumption) were higher, charring woody fuels and duff experience higher average temperatures, explaining our finding of decreased $\mathrm{C}$ concentration and increased $\mathrm{pH}$ at high paint tag temperatures. During wildland fires, particular elements may either increase or decrease in response to increased fire intensity or severity (Santín et al. 2015). Although we observed some significant differences in ash nutrient concentrations among ranked paint tag temperature categories, most elements did not exhibit a clear positive or negative relationship with temperature category. This discrepancy is likely due to the high range of paint tag temperatures experienced in each 


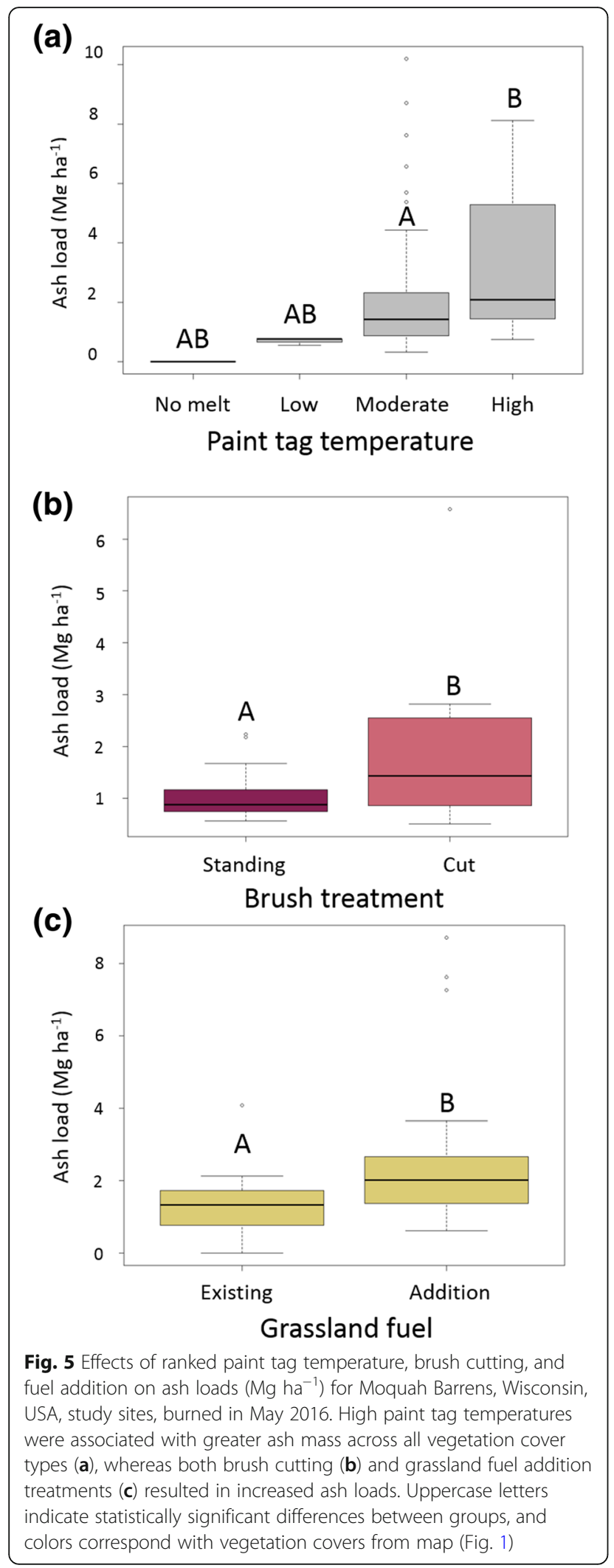

Table 2 Mean total extractable element concentrations for Moquah Barrens, Wisconsin, USA, ash samples collected in May 2016. Samples are distinguished by vegetation cover type, and table excludes ash samples collected from plots with experimental fuel load manipulations (addition or removal). $\mathrm{N}=$ nitrogen, $\mathrm{Fe}=$ iron, $\mathrm{Cu}=$ copper, $\mathrm{Mn}=$ manganese,

$\mathrm{Mg}=$ magnesium, $\mathrm{Ca}=$ calcium, $\mathrm{K}=$ potassium, $\mathrm{P}=$ phosphorus Vegetation cover Total extractable element concentration $\left(\mathrm{g} \mathrm{kg}^{-1}\right)$ \begin{tabular}{lllllllll}
\cline { 2 - 7 } & $\mathrm{N}$ & $\mathrm{P}$ & $\mathrm{K}$ & $\mathrm{Ca}$ & $\mathrm{Mg}$ & $\mathrm{Mn}$ & $\mathrm{Cu}$ & $\mathrm{Fe}$
\end{tabular}

\begin{tabular}{lllllllll}
\hline Standing brush & 16.12 & 2.08 & 4.55 & 23.17 & 4.82 & 2.80 & 0.03 & 5.89
\end{tabular}

$\begin{array}{llllllllll}\text { Grassland } & 15.86 & 1.39 & 2.71 & 18.79 & 4.45 & 2.13 & 0.02 & 6.29\end{array}$

$\begin{array}{llllllllll}\text { Deciduous forest } & 13.00 & 1.87 & 3.58 & 27.26 & 4.68 & 4.46 & 0.03 & 8.62\end{array}$

$\begin{array}{llllllllll}\text { Cut brush } & 13.52 & 1.89 & 3.66 & 22.78 & 5.33 & 4.45 & 0.03 & 8.86\end{array}$

$\begin{array}{lllllllll}\text { Conifer woodland } & 10.44 & 1.18 & 2.35 & 10.30 & 3.38 & 1.44 & 0.02 & 7.71\end{array}$

category, variability of wildland fuels within each vegetation class, and the wide range of temperatures that would be experienced by pyrolyzing materials and ash in the open combustion environment of wildland fires. Finally, based on muffle furnace exposures, high temperature exposure (i.e., $>600{ }^{\circ} \mathrm{C}$ ) during combustion tends to result in fine particle size in ash relative to low temperatures, which has important implications for post-fire runoff and soil erosion (Doerr et al. 2004; Balfour and Woods 2013). For instance, the extent of thermal decomposition of biomass influences post-fire water infiltration rates into soil, although underlying soil particle size and hydrophobicity also determine soil hydrology. Furnace combustion temperatures that are either low or high produce ash that has the greatest potential to form surface seals that decrease post-fire infiltration rates, whereas mid-combustion temperatures form carbonatedominated ash that increases water retention (Balfour and Woods 2013). Balfour and Woods (2013) concluded that peak combustion temperature plays a more important role than fuel type in determining ash hydrologic properties in northwest US conifer forests.

Additional field and laboratory studies have, however, illustrated that the type of fuel combusted also influences ash production and characteristics, which in turn alters runoff and infiltration (Ulery et al. 1993; Ubeda et al. 2009; Bodí et al. 2011; Gabet and Bookter 2011; Yusiharni and Gilkes 2012). The concentration of aromatic carbon (a trait positively related to hydrophobicity) in litter is determined by vegetation source and burn severity (Merino et al. 2015). However, we did not observe significant relationships between PyC (an estimate of fire-produced aromatic C) and either paint tag temperature or vegetation cover. The absence of a statistically significant relationship may be explained in part by the wide range of temperatures included in each temperature category, or by the variability in vegetation composition across our suite of vegetation types. Variability in vegetation 


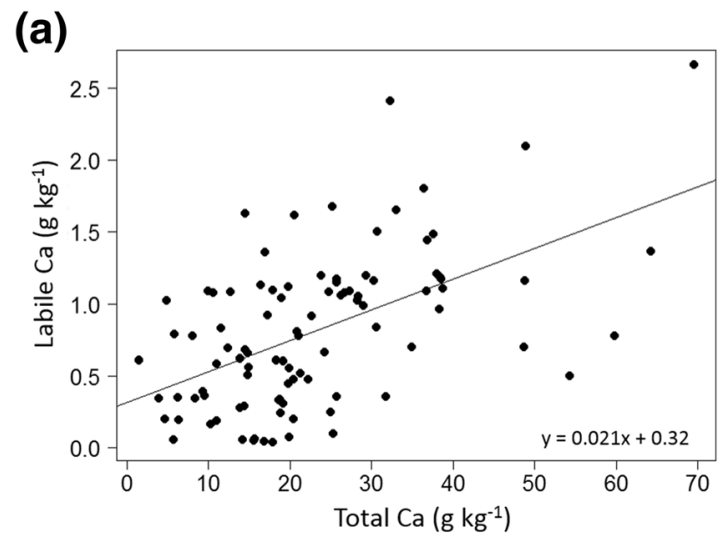

(b)

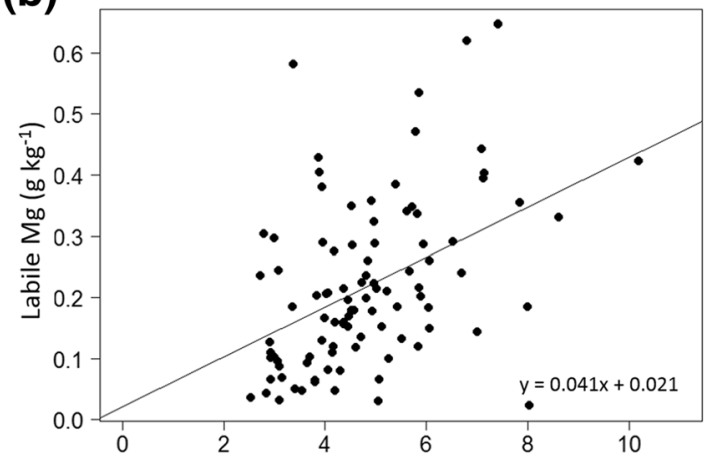

(c) Total Mg $\left(\mathrm{g} \mathrm{kg}^{-1}\right)$

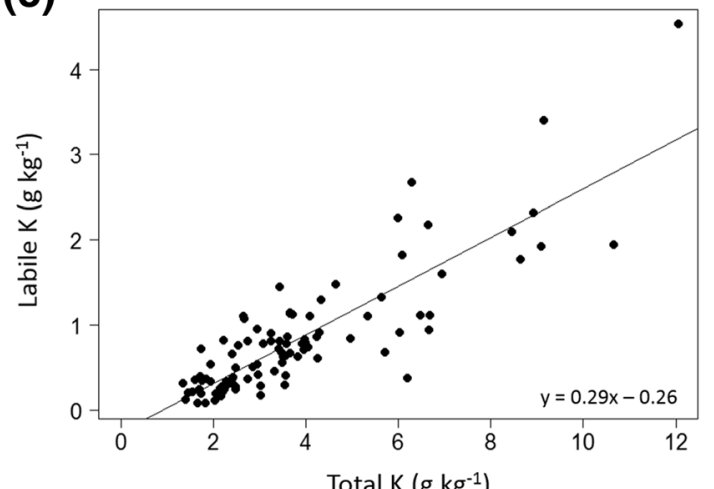

(d)

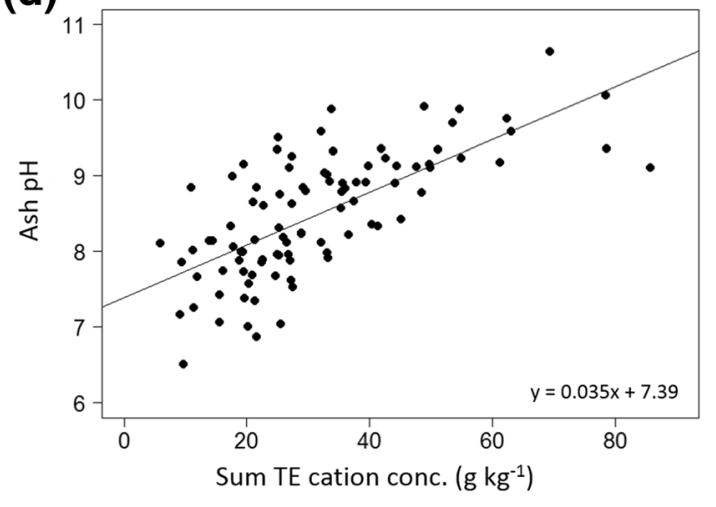

Fig. 6 Leachable cation concentrations of Moquah Barrens, Wisconsin, USA, ash samples were determined by total elemental concentrations and positively related to ash $\mathrm{pH}$. Leachable element (LE) concentration of calcium, $\mathrm{Ca}(\mathbf{a})$; magnesium, $\mathrm{Mg}(\mathbf{b})$; and potassium, $\mathrm{K}(\mathbf{c})$ were all positively related to their total element (TE) concentrations in ash (all $P<0.05$ ). Solid lines represent linear regression fit, and dashed lines show the 1:1 fit. The sum of these three TE cation concentrations (conc.) was positively related to ash $\mathrm{pH}$ (d)

composition can drive fuel time-temperature exposures because vegetation composition influences combustion environments (Mitchell et al. 2009; Hiers et al. 2009; Wagner and Methven 1978).

\section{Relationships between total and leachable ash element concentrations}

Differences in solubility result from temperature-dependent mineralization dynamics, and this may cause measurements of total extractable elements to differ greatly from those of leachable (plant-available) concentrations (Gray and Dighton 2006). Cations tend to be extremely leachable from ash, and a previous study noted a positive relationship between ash leachate $\mathrm{pH}$ and combustion temperature (Plumlee et al. 2007). We observed positive relationships between TEE and LE concentrations for ash $\mathrm{Ca}, \mathrm{Mg}$, and $\mathrm{K}$. Cation LE concentrations in ash from our study were greater than those reported for ash from wildfires in shrubby Australian eucalypt forest (Santín et al. 2015, 2018) and less than those reported for ash from a low-severity prescribed fire in a Spanish cork oak (Quercus suber L.) forest (Pereira et al. 2011). In our study, LE P was not related to TE P, likely due to its very narrow $\mathrm{pH}$ range of solubility. However, a column leaching experiment indicated that increased soil alkalinity associated with ash input resulted in a 3- to 10-fold increase in upper mineral soil extractable P (Escudey et al. 2010). Plants commonly experience $\mathrm{Fe}$ and $\mathrm{Mn}$ deficiency despite their high abundance in soils, so even small pulses of leachable metals may be vital for plant responses following fire (McBride 1989).

Nutrient stocks and implications for barrens management Fire can help maintain a nutrient-poor soil status in barrens by mineralizing and mobilizing nutrients, which are then lost by leaching through coarse-textured and well drained to excessively drained sandy soils such as occur in our study site. While stocks of total extractable nutrients in ash in our study were greatest for $\mathrm{Ca}, \mathrm{Fe}$, and $\mathrm{N}$, we expect that prescribed fire will decrease their concentrations in the Moquah Barrens soils over time via leaching after each successive burn. Tree growth in barrens communities is effectively limited by deficiencies of $\mathrm{Ca}$, $\mathrm{Mg}$, and $\mathrm{N}$, and by low soil moisture content (Sweet 


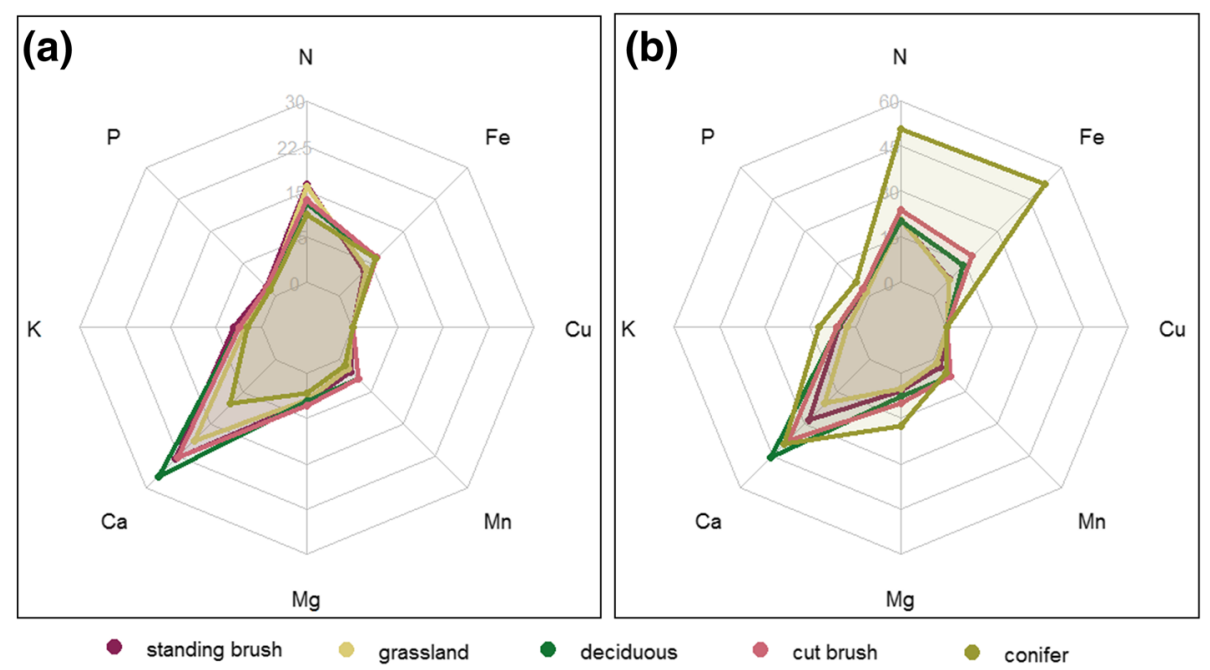

Fig. 7 Radar plots for Moquah Barrens, Wisconsin, USA, study sites, burned in May 2016, showing differences in ash total extractable element (TEE) concentrations (mg element $\mathrm{kg}^{-1}$ ash, a) and ash nutrient stocks $\left(\mathrm{Mg} \mathrm{ha}^{-1}, \mathbf{b}\right)$ among vegetation cover types with ambient fuel loads (no fuel addition or removal). $\mathrm{N}=$ nitrogen, $\mathrm{Fe}=$ iron, $\mathrm{Cu}=$ copper, $\mathrm{Mn}=$ manganese, $\mathrm{Mg}=$ magnesium, $\mathrm{Ca}=$ calcium, $\mathrm{K}=$ potassium, $\mathrm{P}=$ phosphorus . Refer to results for significant nutrient stock differences among vegetation types

1880; Heikens and Robertson 1994). A previous study of northern Great Lakes states soils suggests that high C:N ratios (above 30:1) in the forest floor of jack pine, red pine, balsam fir (Abies balsamea [L.] Mill.), maple, and quaking aspen (Populus tremuloides) forests result in net immobilization of $\mathrm{N}$ and limit tree growth (David et al. 1988). The negative relationships we observed between paint tag temperatures and $\mathrm{N}$ concentration in ash suggest that achieving high temperatures in pyrolyzing fuels and ash during prescribed burns results in greater nitrogen volatilization and may be ideal for limiting post-fire soil $\mathrm{N}$ inputs. In the absence of prescribed fire, succession toward mesic species occurs, as has been observed in similar glacial outwash systems in Minnesota (McAndrews 1966; Scherer et al. 2017) and generally throughout the eastern United States (Nowacki and Abrams 2008). In the Moquah Barrens area, a similar pattern of woody plant encroachment may occur under fire exclusion, resulting in ecologically disruptive effects such as altered vegetation structure, reduced plant diversity, and, ultimately, decreased habitat size and quality for local fauna (VanAuken 2009). Sharp-tailed grouse (Tympanuchus phasianellus campestris Ridgeway) and the Karner blue butterfly (Lycaeides melissa samuelis L.) are examples of local species of concern that require large areas of early successional habitat maintained by frequent fire (Niemuth and Boyce 2004).

Vegetation cover type was the major determinant of ash nutrient stocks for certain elements, but leachable nutrient concentrations are not necessarily determined by total element concentrations. Inputs of soluble cations from ash can affect soil exchangeable cations and $\mathrm{pH}$ for several years and have a major impact on nutrient solubility (Khanna et al. 1996), and therefore plant-available nutrients. Because vegetation cover type (i.e., grassland, conifer woodland, and deciduous forest) influences the amount and $\mathrm{pH}$ of ash, land managers may need to tailor their management efforts or timelines for achieving desired edaphic changes according to vegetation community type. For instance, seasonality of burn would likely have consequences for both the quantity and quality of ash produced. Prescribed burns in the Moquah Barrens are typically conducted during spring, when many nutrient resources are being stored belowground in forests (i.e., in plant roots). Burning after nutrients are translocated to aboveground biomass may offer a more effective strategy for decreasing nutrient stocks. However, further experimentation is needed to better understand whether the nutrients contained in ash are retained in soils or leached, and over what time period after fire. A full nutrient budget accounting for plant uptake, leaching in the absence of fire, and frequency of prescribed burns is needed to provide insight into the importance of nutrient losses or inputs from ash. Finally, timber harvest is prevalent in the Chequamegon-Nicolet National Forest, and it is worth noting that, in forested areas, fire plays an important role in recycling nutrients from understory vegetation into forms available for uptake by overstory trees (Vogl 1970). Thus, fire may play a diverse role in this mosaic landscape by preventing woody encroachment in open barrens and sustaining biomass yield for timber harvest in forests. 


\section{Conclusions}

Our study suggests that high fuel and ash temperatures (which we expect are correlated with surface paint tag temperatures) during prescribed burns result in greater nitrogen volatilization, indicating that prescribed fires implemented under conditions that lead to more intense fires with greater fuel consumption, while still minimizing associated risks, will be more effective for limiting post-fire inputs of $\mathrm{N}$ from ash, relative to fires implemented under conditions that minimize fire intensity. Understanding variation in ash properties has implications for post-fire management, specifically by elucidating relationships among vegetation cover type, ash, and soils. The effects of ash in situ are typically ephemeral and dependent upon post-fire weather conditions. However, in some situations, ash may form stable crusts resistant to redistribution by wind, with the potential for long-lasting effects on soils and vegetation (Balfour et al. 2014). Our study suggests that fuel manipulations, vegetation cover type, maximum paint tag temperatures, and fuel consumption (estimated from maximum paint tag temperatures and related to fire energy) all influence the amount and composition of ash produced by prescribed fire. Concentrations of leachable elements released from ash are more difficult to predict than total nutrient stocks because solubility is influenced by soil $\mathrm{pH}$ and mineralogy. To advance knowledge about the ecological significance of wildland fire ash, future studies should address how in situ soil properties and post-fire environmental conditions (i.e., precipitation, wind) interact to influence the magnitude and spatiotemporal persistence of ash nutrient inputs.

\section{Additional file}

Additional file 1: S1. Calibrated fuel consumption from maximum paint tag temperature. Table S2. Mean total extractable (TE) element concentrations, in $\mathrm{g}$ element $\mathrm{kg}^{-1}$ ash, by paint tag temperature categories. $\mathrm{N}=$ nitrogen, $\mathrm{Fe}=$ iron, $\mathrm{Cu}=$ copper, $\mathrm{Mn}=$ manganese, $\mathrm{Mg}=$ magnesium, $\mathrm{Ca}=$ calcium, $\mathrm{K}=$ potassium, $\mathrm{P}=$ phosphorus. Table excludes plots that were subject to fuel manipulations. Table S3. Mean leachable element (LE) concentrations, in g element $\mathrm{kg}^{-1}$ ash, by vegetation cover. $\mathrm{Fe}=$ iron, $\mathrm{Cu}=$ copper, $\mathrm{Mn}=$ manganese, $\mathrm{Mg}=$ magnesium, $\mathrm{Ca}=$ calcium, $\mathrm{K}=$ potassium, $\mathrm{P}=$ phosphorus. Table excludes plots that were subject to fuel manipulations. (DOCX $28 \mathrm{~kb}$ )

\section{Acknowledgments}

We thank the many field crew and lab members who assisted with this study, especially K. Witt, B. Smith, D. Uhelski, H. Jensen, T. Roman, A. Wiese, B. Miranda, T. Paul, B. Borovicka, B. Maestrini, and J. Jolliff. We also thank J. Rabuck, M. Bushman, B. Heeringa, V. Hazelton, M. Davalo, D. Hinson, and additional personnel from the Washburn Ranger District, Chequamegon-Nicolet National Forest; and J. Maloney, J. Cook, and other personnel from the Northern Great Lakes Visitors Center for providing vital resources and for their assistance with project planning and burn operations. M. Bushman further contributed valuable local expertise guiding the development of our study design, and S. Lietz contributed GIS mapping activities necessary for study area stratification and plot locations. We thank P. Pierera for suggesting the collection of ash samples, and the Michigan State University (MSU) Postdoctoral Association for providing a travel award to K. Quigley to present preliminary findings at the 7th International Fire Ecology and Management Congress. Finally, we thank S. Virden and W. Wiggins of the Bureau of Indian Affairs (Michigan Agency) for assistance obtaining National Wildfire Coordinating Group incident qualifications for MSU personnel.

\section{Funding}

This work was funded by a Joint Fire Science Program (JFSP) grant awarded to B. Sturtevant, J. Miesel, M. Dickinson, C. Kern, R. Kolka, and D. Donner for the project titled, "Manipulating soil heating patterns to optimize barrens restoration" (Project ID: 15-1-05-13). R. Wildt was funded in part by a Michigan State University College of Agriculture and Natural Resources Undergraduate Research Program (CANR-URP) award. B. Sturtevant and M. Dickinson were supported by the US Forest Service Northern Research Station and the National Fire Plan.

Availability of data and materials

Please contact author for data requests.

Authors' contributions

$\mathrm{BS}, \mathrm{RK}, \mathrm{JM}, \mathrm{MD}$, and CK contributed to the study design and all authors contributed to data collection. RW processed laboratory samples. KQ analyzed data and wrote the first manuscript draft. All coauthors made substantial contributions to revisions. All authors read and approved the final manuscript.

Ethics approval and consent to participate

Not applicable.

\section{Consent for publication}

Not applicable.

\section{Competing interests}

The authors declare that they have no competing interests.

\section{Publisher's Note}

Springer Nature remains neutral with regard to jurisdictional claims in published maps and institutional affiliations.

\section{Author details}

${ }^{1}$ Department of Plant, Soil, and Microbial Sciences, Michigan State University, 1066 Bogue Street, East Lansing, MI 48824-1222, USA. 'Department of Fisheries and Wildlife, Michigan State University, 480 Wilson Road, East Lansing, MI 48824-1222, USA. ${ }^{3}$ USDA Forest Service, Northern Research Station, 5985 Hwy K, Rhinelander, WI 54501, USA. ${ }^{4}$ USDA Forest Service, Northern Research Station, 1831 Hwy 169 E, Grand Rapids, MN 55744, USA. ${ }^{5}$ USDA Forest Service, Northern Research Station, 359 Main Road, Delaware, $\mathrm{OH}$ 43015, USA.

Received: 16 June 2018 Accepted: 24 September 2018

Published online: 21 March 2019

\section{References}

Balfour, V.N., S.H. Doerr, and P.R. Robichaud. 2014. The temporal evolution of wildfire ash and implications for post-fire infiltration. International Journal of Wildland Fire 23: 733-745. https://doi.org/10.1071/WF13159.

Balfour, V.N., and S.W. Woods. 2013. The hydrological properties and the effects of hydration on vegetative ash from the northern Rockies, USA. Catena 111: 9-24. https://doi.org/10.1016/j.catena.2013.06.014.

Baxter, B.J.M., J. Van Staden, J.E. Granger, and N.A.C. Brown. 1994. Plant-derived smoke and smoke extracts stimulate seed germination of the fire-climax grass Themeda triandra. Environmental and Experimental Botany 34: 217-223. https://doi.org/10.1016/0098-8472(94)90042-6.

Bodi, M.B., D.A. Martin, V.N. Balfour, C. Santin, S.H. Doerr, P. Pereira, A. Cerda, and J. Mataix-Solera. 2014. Wildland fire ash: Production, composition and ecohydro-geomorphic effects. Earth-Science Reviews 130: 103-127. https://doi. org/10.1016/j.earscirev.2013.12.007.

Bodí, M.B., J. Mataix-Solera, S.H. Doerr, and A. Cerdà. 2011. The wettability of ash from burned vegetation and its relationship to mediterranean plant species type, burn severity and total organic carbon content. Geoderma 160: 599607. https://doi.org/10.1016/j.geoderma.2010.11.009. 
Bond, W.J., and J.E. Keeley. 2005. Fire as a global "herbivore": the ecology and evolution of flammable ecosystems. Trends in Ecology \& Evolution 20: 387394. https://doi.org/10.1016/j.tree.2005.04.025.

Bova, A.S., and M.B. Dickinson. 2008. Beyond "fire temperatures": calibrating thermocouple probes and modeling their response to surface fires in hardwood fuels. Canadian Journal of Forest Research 38: 1008-1020. https:// doi.org/10.1139/X07-204.

Busenberg, G. 2004. Wildfire management in the United States: the evolution of a policy failure. Review of Policy Research 21: 145-156. https://doi.org/10.1111/ j.1541-1338.2004.00066.x.

Campos, I., N. Abrantes, J.J. Keizer, C. Vale, and P. Pereira. 2016. Major and trace elements in soils and ashes of eucalypt and pine forest plantations in Portugal following a wildfire. Science of the Total Environment 572: $1363-$ 1376. https://doi.org/10.1016/j.scitotenv.2016.01.190.

Curtis, J.T. 1959. The vegetation of Wisconsin. Madison: University of Wisconsin Press.

David, M.B., D.F. Grigal, L.F. Ohmann, and G.Z. Gertner. 1988. Sulfur, carbon and nitrogen relationships in forest soils across the northern Great Lakes states as affected by atmospheric deposition and vegetation. Canadian Journal of Forest Research 18: 1386-1391. https://doi.org/10.1139/x88-216.

Doerr, S.H., W.H. Blake, R.A. Shakesby, F. Stagnitti, S.H. Vuurens, G.S. Humphreys, and P. Wallbrink. 2004. Heating effects on water repellency in Australian eucalypt forest soils and their value in estimating wildfire soil temperatures. International Journal of Wildland Fire 13: 157-163. https://doi.org/10.1071/WF03051.

Escudey, M., N. Arancibia-Miranda, C. Pizarro, and M. Antilén. 2015. Effect of ash from forest fires on leaching in volcanic soils. Catena 135: 383-392. https:// doi.org/10.1016/j.catena.2014.08.006

Escudey, M., P. De La Fuente, M. Antiĺn, and M. Molina. 2010. Effect of ash from forest fires on phosphorus availability, transport, chemical forms, and content in volcanic soils. Environment and Chemistry 7: 103-110. https://doi.org/10. 1071/EN09067.

Fernandes, P.M., G.M. Davies, D. Ascoli, C. Fernández, F. Moreira, E. Rigolot, C.R. Stoof, J.A. Vega, and D. Molina. 2013. Prescribed burning in southern Europe: developing fire management in a dynamic landscape. Frontiers in Ecology and the Environment 11: e4-e14. https://doi.org/10.1890/120298.

Gabet, E.J., and A. Bookter. 2011. Physical, chemical and hydrological properties of ponderosa pine ash. International Journal of Wildland Fire 20: 443-452. https://doi.org/10.1071/WF09105.

Glasspool, I.J., D. Edwards, and L. Axe. 2004. Charcoal in the Silurian as evidence for the earliest wildfire. Geology 32: 381-383. https://doi.org/10.1130/G20363.1.

Gray, D.M., and J. Dighton. 2006. Mineralization of forest litter nutrients by heat and combustion. Soil Biology and Biochemistry 38: 1469-1477. https://doi.org/ 10.1016/j.soilbio.2005.11.003.

Guyette, R.P., M.C. Stambaugh, D.C. Dey, J.M. Marschall, J. Saunders, and J. Lampereur. 2016. 350 years of fire-climate-human interactions in a Great Lakes sandy outwash plain. Forests 7 (9): 189. https://doi.org/10.3390/f7090189.

Hageman, P.L. 2007. US Geological Survey field leach test for assessing water reactivity and leaching potential of mine wastes, soils, and other geologic and environmental materials, US Geological Survey techniques and methods, book 5, chapter D3. Reston: USDI, US Geological Survey.

Heikens, A.L., and P.A. Robertson. 1994. Barrens of the Midwest: a review of the literature. Castanea 59: 184-194.

Hiers, J.K., J.J. O'Brien, R.J. Mitchell, J.M. Gregoand, and E.L. Loudermilk. 2009. The wildland fuel cell concept: an approach to characterize fine-scale variation in fuels and fire in frequently burned longleaf pine forests. International Journal of Wildland Fire 18 (3): 315-325.

Hogue, B.A., and P.W. Inglett. 2012. Nutrient release from combustion residues of two contrasting herbaceous vegetation types. Science of the Total Environment 431: 9-19. https://doi.org/10.1016/j.scitotenv.2012.04.074.

Jiménez-Pinilla, P., E. Lozano, J. Mataix-Solera, V. Arcenegui, A. Jordán, and L.M. Zavala. 2016. Temporal changes in soil water repellency after a forest fire in a Mediterranean calcareous soil: influence of ash and different vegetation type. Science of the Total Environment 572: 1252-1260. https://doi.org/10.1016/j. scitotenv.2015.09.121.

Khanna, P., B. Ludwig, and R. Raison. 1996. Comparing modelled and observed effects of ash additions on chemistry of a highly acid soil. Australian Journal of Soil Research 34: 999. https://doi.org/10.1071/SR9960999.

Kurth, V.J., M.D. Mackenzie, and T.H. Deluca. 2006. Estimating charcoal content in forest mineral soils. Geoderma 137: 135-139. https://doi.org/10.1016/j. geoderma.2006.08.003.

Leach, M.K., and T.J. Givnish. 1996. Ecological determinants of species loss in remnant prairies. Science 273: 1555-1558. https://doi.org/10.1126/science.273.5281.1555.
Liodakis, S., M. Tsoukala, and G. Katsigiannis. 2009. Laboratory study of leaching properties of Mediterranean forest species ashes. Water, Air, and Soil Pollution 203: 99-107. https://doi.org/10.1007/s11270-009-9994-y.

Lutes, D.C., R.E. Keane, J.F. Caratti, C.H. Key, N.C. Benson, S. Sutherland, and L.J. Gangi. 2006. FIREMON: fire effects monitoring and inventory system. USDA Forest Service General Technical Report RMRS-GTR-164-CD. Fort Collins: Rocky Mountain Research Station.

Maestrini, B., and J.R. Miesel. 2017. Modification of the weak nitric acid digestion method for the quantification of black carbon in organic matrices. Organic Geochemistry 103: 136-139. https://doi.org/10.1016/j.orggeochem.2016.10.010.

McAndrews, J.H. 1966. Postglacial history of prairie, savanna, and forest in northwestern Minnesota. Memoirs of the Torrey Botanical Club 22: 1-72.

McBride, M.B. 1989. Reactions controlling heavy metal solubility in soils. In Advances in soil science, ed. B.A. Stewart, vol. 10, 1-47. New York: SpringerVerlag. https://doi.org/10.1007/978-1-4613-8847-0_1.

Merino, A., B. Chávez-Vergara, J. Salgado, M.T. Fonturbel, F. García-Oliva, and J.A. Vega. 2015. Variability in the composition of charred litter generated by wildfire in different ecosystems. Catena 133: 52-63. https://doi.org/10.1016/j. catena.2015.04.016.

Mitchell, R.J., J.K. Hiers, J. O'Brien, and G. Starr. 2009. Ecological forestry in the Southeast: understanding the ecology of fuels. Journal of Forestry 107: 391-397.

Niemuth, N.D., and M.S. Boyce. 2004. Influence of landscape composition on sharp-tailed grouse lek location and attendance in Wisconsin pine barrens. Ecoscience 11: 209-217. https://doi.org/10.1080/11956860.2004.11682826.

Noss, R.F., E.T. LaRoe III, and J.M. Scott. 1995. Endangered ecosystems of the United States: a preliminary assessment of loss and degradation, USDI National Biological Service Biological Report 28. Washington, D.C..

Nowacki, G.J., and M.D. Abrams. 2008. The demise of fire and "mesophication" of forests in the eastern United States. BioScience 58: 123-138. https://doi.org/ 10.1641/B580207.

NPS [National Park Service]. 2003. Fire monitoring handbook. Boise: National Interagency Fire Center, Fire Management Program.

Olsen, S., C. Cole, and L. Dean. 1954. Estimation of available phosphorus in soils by extraction with sodium bicarbonate, US Department of Agriculture Circular No. 939. Washington, D.C.

Pereira, P., X. Beda, D. Martin, J. Mataix-Solera, and C. Guerrero. 2011. Effects of a low severity prescribed fire on water-soluble elements in ash from a cork oak (Quercus suber) forest located in the northeast of the Iberian Peninsula. Environmental Research 111: 237-247. https://doi.org/10.1016/j.envres.2010.09.002.

Pereira, P. X. Ubeda, and D.A. Martin. 2012. Fire severity effects on ash chemical composition and water-extractable elements. Geoderma 191: 105-114. https://doi.org/10.1016/j.geoderma.2012.02.005.

Plumlee, G.S., D. a Martin, T. Hoefen, R. Kokaly, A. Eckberg, G. P. Meeker, M. Adams, M. Anthony, and P.J. Lamothe. 2007. Preliminary analytical results for ash and burned soils from the October 2007 southern California wildfires. USDI, US Geological Survey Open-File Report 2007-1407, Reston, Virginia, USA.

R Development Core Team. 2014. R: a language and environment for statistical computing. Vienna: R Foundation for Statistical Computing.

Radeloff, V.C., D.J. Mladenoff, H.S. He, and M.S. Boyce. 1999. Forest landscape change in the northwestern Wisconsin pine barrens from pre-European settlement to the present. Canadian Journal of Forest Research 29: 1649-1659. https://doi.org/10.1139/x99-089.

Raison, R.J. 1979. Modification of the soil environment by vegetation fires, with particular reference to nitrogen transformations: a review. Plant and Soil 51 73-108. https://doi.org/10.1007/BF02205929.

Ryan, K.C., E.E. Knapp, and J.M. Varner. 2013. Prescribed fire in North American forests and woodlands: history, current practice, and challenges. Frontiers in Ecology and the Environment 11: e15-e24. https://doi.org/10.1890/120329.

Santín, C., S.H. Doerr, X.L. Otero, and C.J. Chafer. 2015. Quantity, composition and water contamination potential of ash produced under different wildfire severities. Environmental Research 142: 297-308. https://doi.org/10.1016/j. envres.2015.06.041

Santín, C., X.L. Otero, S.H. Doerr, and C.J. Chafer. 2018. Impact of a moderate/ high-severity prescribed eucalypt forest fire on soil phosphorous stocks and partitioning. Science of the Total Environment 621: 1103-1114. https://doi.org/ 10.1016/j.scitotenv.2017.10.116.

Scherer, S.S., C.C. Kern, A.W. D'Amato, B.J. Palik, and M.R. Russell. 2017. Long-term pine regeneration, shrub layer dynamics, and understory community composition responses to repeated prescribed fire in Pinus resinosa forests. Canadian Journal of Forest Research 129: 117-129. 
Soil Survey Staff. 1999. Soil taxonomy: a basic system of soil classification for making and interpreting soil surveys. In Agriculure Handbook 436, Second ed. Washington, D.C: USDA Natural Resources Conservation Service.

Sweet, E.T. 1880. Geology of western Lake Superior district. Chapter 1: surface features. In Geology of Wisconsin. Survey of 1873-1879, chief geologist. T.C. Chamberlin, vol. III, 310-329. Madison: The Commissioners of Public Printing. Taft, J.B. 2003. Fire effects on community structure, composition, and diversity in a dry sandstone barrens. Journal of the Torrey Botanical Society 130: 170-192. https://doi.org/10.2307/3557552.

Tuininga, A.R., and J. Dighton. 2004. Changes in ectomycorrhizal communities and nutrient availability following prescribed burns in two upland pine-oak forests in the New Jersey pine barrens. Canadian Journal of Forest Research 34: 1755-1765. https://doi.org/10.1139/x04-037.

Tweiten, M.A., R.R. Calcote, E.A. Lynch, S.C. Hotchkiss, and G.W. Schuurman. 2015. Geophysical features influence the climate change sensitivity of northern Wisconsin pine and oak forests. Ecological Applications 25: 1984-1996. https:// doi.org/10.1890/14-2015.1

Ubeda, X., P. Pereira, L. Outeiro, and D.A. Martin. 2009. Effects of fire temperature on the physical andd chemical characteristics of the ash from two plots of cork oak (Quercus suber). Land Degradation and Development 20: 589-608. https://doi.org/10.1002//dr.930.

Ulery, A.L., R.C. Graham, and C. Amrhein. 1993. Wood-ash composition and soil pH following intense burning. Soil Science 156: 358-364. https://doi.org/10. 1097/00010694-199311000-00008.

USDA Forest Service. 2013. Final Environmental Impact Statement: Lakewood Southeast Project. Lakewood-Laona Ranger District, Lakewood: USDA Forest Service.

Uys, R.G., W.J. Bond, and T.M. Everson. 2004. The effect of different fire regimes on plant diversity in southern African grasslands. Biological Conservation 118: 489-499. https://doi.org/10.1016/j.biocon.2003.09.024.

VanAuken, O.W. 2009. Causes and consequences of woody plant encroachment into western North American grasslands. Journal of Environmental Management 90: 2931-2942. https://doi.org/10.1016/j.jenvman.2009.04.023.

Vogl, R.J. 1970. Fire and the northern Wisconsin pine barrens. Proceedings of the annual Tall Timbers Fire Ecology Conference 10: 175-209.

Vora, R.S. 1993. Moquah Barrens: pine barrens restoration experiment initiated in Chequamegon National Forest. Restoration \& Management Notes 11: 39-44.

Wagner, C.V., and I.R. Methven. 1978. Two recent articles on fire ecology. Canadian Journal of Forest Research 8 (4): 491-492.

Wan, S., D. Hui, and Y. Luo. 2001. Fire effects on nitrogen pools and dynamics in terrestrial ecosystems: a meta-analysis. Ecological Applications 11: 1349-1365.

Wisconsin DNR [Wisconsin Department of Natural Resources]. 2015. Assessment of current conditions. Chapter 2. In The ecological landscapes of Wisconsin: an assessment of ecological resources and a guide to planning sustainable management, ed. P. Duyfhuizen, C-1-C-174. Madison: Wisconsin Depatment of Natural Resources publication PUB-SS-1131C 2015.

Yusiharni, E., and R. Gilkes. 2012. Minerals in the ash of Australian native plants. Geoderma 189-190: 369-380. https://doi.org/10.1016/j.geoderma.2012.06.035.

Zheng, W., E.K. Morris, A. Lehmann, and M.C. Rillig. 2016. Interplay of soil water repellency, soil aggregation and organic carbon. A Meta-analysis. Geoderma 283: 39-47. https://doi.org/10.1016/j.geoderma.2016.07.025.

\section{Submit your manuscript to a SpringerOpen ${ }^{\circ}$ journal and benefit from:}

- Convenient online submission

- Rigorous peer review

- Open access: articles freely available online

- High visibility within the field

- Retaining the copyright to your article

Submit your next manuscript at $\boldsymbol{\nabla}$ springeropen.com 